\title{
Impacts of Institutional Characteristics on International Students' Choice of Private Higher Education Institutions in Malaysia
}

\author{
Melissa W. Migin ${ }^{1}$, Mohammad Falahat ${ }^{2}$, Mohd Shukri Ab Yajid ${ }^{3} \&$ Ali Khatibi ${ }^{3}$ \\ ${ }^{1}$ UCSI University, Kuala Lumpur, Malaysia \\ ${ }^{2}$ Universiti Tunku Abdul Rahman (UTAR), Selangor Darul Ehsan, Malaysia \\ ${ }^{3}$ Management \& Science University (MSU), Selangor Darul Ehsan, Malaysia \\ Correspondence: Melissa W. Migin, Faculty of Business \& Information Science, UCSI University, Kuala Lumpur, \\ Malaysia. Tel: 60-3-9101-8880. E-mail: melissamigin@ucsiuniversity.edu.my
}

Received: December 10, 2014

doi: $10.5539 /$ hes.v5n1p31
Accepted: January 8, $2015 \quad$ Online Published: January 21, 2015

URL: http://dx.doi.org/10.5539/hes.v5n1p31

\begin{abstract}
In recent years, Malaysia has witnessed an influx of foreign students in the local higher education institutions with the aggressive support from the Malaysian government to build Malaysia as the educational hub within the region. This is in line with Malaysia's aspiration to be a global education hub by year 2020 .

Besides the country level policy, the aim of this study is to understand the major drivers that influence foreign students to choose Malaysia and the private HEI as their study destination. Five dimensions were employed in measuring student's choice of private HEI with a focus on institutional characteristics (cost of education, academic reputation, location, programme and facilities). A sample of 265 respondents was drawn within five private HEIs and the Structural Equation Model (SEM) was utilized in testing the five proposed hypotheses. Based on the findings, all hypotheses were significant except for location. This study gave an idea that institutional characteristics are significantly important in measuring foreign students' choice of Malaysian private HEI.

In conclusion, these findings would enable academics and practitioners to focus on the crucial factors that influence foreign students to choose their respective private HEIs.
\end{abstract}

Keywords: institutional characteristics, private HEI, foreign students, SEM, Malaysia

\section{Introduction}

In many developed countries, the international trade in educational services is a major source of income; it has become a multi-billion dollar business (Cheung, Yuen, Yuen, \& Cheng, 2011). Given the benefits to individual higher education institutions, and the economic impact on the nation at large, there is an on-going global race for international enrolment of students, in which Malaysia has also entered.

By the 1990s, Malaysia was among the top countries with students studying in the USA, the UK and Australia. Inevitably, the Malaysian government would be faced with the high cost of financing the large number of government sponsored students studying abroad. The volatile foreign currency exchange and the escalation of overseas education costs meant that the country's annual overseas education expenses were rising. Another contributory factor was the Asian Financial Crisis which started in Thailand in July 1996 and moved to the rest of Asia.

Realising the danger of continuous currency outflow, the Malaysian government sought to rectify the situation by working on a series of restructuring strategies. The strategies steered for the growth and development of the Malaysian Higher Education system and the encouragement of the private sector to participate in the restructuring plan (Migin, Yajid, Khatibi, \& Falahat, 2014). The national aspiration is to not only cultivate first-class human capital and creating social mobility, but also as an engine of growth in its own right (Economic Transformation Programme, 2010). The vision set by the government is to develop Malaysia into a regional centre for excellence in tertiary education. Under the Economic Transformation Programme (ETP), 12 National Key Result Areas (NKRA) were listed out and education was identified as one of the sectors that would accelerate Malaysia's growth towards a high-income developed nation status by year 2020. The education sector 
contributed approximately RM27 billion or 4 percent of Gross National Income (GNI) in the year 2009 (REHDA Institute, 2010).

Due to the government's persevering effort in promoting Malaysia as a regional educational hub, Malaysia was ranked as $11^{\text {th }}$ largest exporter of higher education among foreign students (UNESCO Institute of Statistics, 2008). The then MoHE objective is to enroll 150,000 foreign students by 2015 and 200,000 by year 2020 . The internationalization policy was formulated to achieve the targeted number of foreign students by year 2020 (MoHE, 2010).

\section{Problem Statement}

It is predicted that the number of foreign students will reach a total of 7.2 million by the year 2025 (Banks, Olsen $\&$ Pearce, 2007). This has made the competition to attract foreign students among hosting countries more intense as years go by. Upcoming regional education hubs in neighbouring countries such as Thailand, Singapore, China and Japan are aggressively promoting their higher education institutions.

Being a late comer (in comparison to major hosting countries such as the Australia and Singapore) in an already competitive market, Malaysian private HEI will encounter significant challenges in order to meet the target of reaching 200,000 foreign students by year 2020 and being the international higher education hub.

In the year 2008, a total number of 50,679 foreign students enrolled in private institutions and further increased to 58,294 foreign students in 2009. As for the year 2010, foreign students' numbers increased as much as 8 percent with a total number of 62,705 as shown in Table 1. However the total numbers dropped for year 2011, with 45,246 foreign students studying in private HEIs, at a reduction of 27 percent from the previous year.

Table 1. Enrolment of foreign students in private HEI, 2008-2011

\begin{tabular}{lllll}
\hline Year & 2008 & 2009 & 2010 & 2011 \\
\hline $\begin{array}{l}\text { Enrollment of Foreign Students in Private Higher Education } \\
\text { Institutions }\end{array}$ & 50,679 & 58,294 & 62,705 & 45,246 \\
$\%$ difference from previous year & & $15 \%$ & $8 \%$ & $-27 \%$ \\
\hline
\end{tabular}

Source: Ministry of Higher Education (MOHE) (2012)

Private HEI with university status has managed to attract and enroll foreign students to their institutions and the total number of foreign students increased from year 2010 to 2011 from 15,455 to 25,884, as shown in Table 2 . However other private HEIs did not manage to attract a significant number of foreign students. It is unclear on the reasons of foreign students choosing one private higher education institution from the other. Due to the fact that foreign students come from different cultures, levels of Westernization and the communication infrastructure varies in accordance to their home countries may lead to different marketing communication preferences. This makes it more complicated for private higher education institutions to determine which methods is the best to be used to attract foreign students to study in Malaysia. In view of that, this study aims to identify the influential factors that attract foreign students in choosing private HEI in Malaysia. This is in line with the target of exporting education services overseas while the public HEI fulfils Malaysia's agenda on nation building through education.

Table 2. Number of students for enrolment according to private HEI status, 2010-2011

\begin{tabular}{|c|c|c|c|}
\hline Private HEI Status & $\begin{array}{l}\text { Total } \\
(\text { Y2011) }\end{array}$ & $\begin{array}{ll}\text { No. } & \text { Total } \\
& \text { Students }\end{array}$ & $\begin{array}{l}\text { No. } \\
\text { Institutions } \\
\text { (Y2011) }\end{array}$ \\
\hline Private HEI with university status & 25,884 & 25,884 & 28 \\
\hline $\begin{array}{l}\text { Private HEI with university status (Branch campus of } \\
\text { foreign university) }\end{array}$ & 1,893 & 19,362 & 5 \\
\hline Private HEI with university college status & 7,340 & & 21 \\
\hline Private HEI with college status & 10,129 & & 415 \\
\hline
\end{tabular}

Source: Ministry of Higher Education (MOHE) (2012) 


\section{Literature Review}

Cost of education has been the most studied factor in influencing student's choice of a particular college or university. Cost of education can only be the tuition fees or it can also refer to the tuition fees along with the cost of living and travel expenses in a foreign country. When studying in any Malaysian higher education institutions, foreign students are not allowed to work full-time and therefore they need to consider their living expenses during their time of study. Many studies have stated that cost of education is important (Padlee, Kamaruddin, \& Baharun, 2010; Wagner \& Fard, 2009; Ghazali \& Kassim, 2003; Mazzarol \& Soutar, 2002; Joseph \& Joseph, 1998).

Students in general highly consider the cost of education before deciding on the university that they want to study in. This applies in different countries, namely New Zealand (Joseph \& Joseph, 1998), Indonesia (Joseph \& Joseph, 2000), Australia (Mazzarol \& Soutar, 2002) and Malaysia (Padlee et al., 2010; Wagner \& Fard, 2009; Ghazali \& Kassim, 2003). Despite the belief that foreign students are wealthy, research has shown that cost of education is an important factor in choosing their place of study. Dora et al. (2009) examined the 6 factors of foreign students on choosing Malaysia's public universities as their study destination and their findings show that one of the main reasons is due to the competitive overall costs of studying in Malaysia.

The academic reputation is the private institutions' capacity to positively position itself in the minds of the students. The main obstacle in studying reputation as a factor is because it is not always measurable. It is more towards the students' perceptions or statements from the private institutions. However, reputation is undeniably influential in which the empirical findings that show reputation is consistently ranked as the most important factor in the students' selection of a college/university (Beneke \& Human, 2010; Nagaraj et al., 2008; Baharun 2004; LeBlanc \& Nguyen, 1997).

Due to the increase of private institutions, students are more careful in choosing their colleges/universities. It is believed that when students graduate from a reputable university, there are more opportunities to get employed easily or it is some form of guarantee that the students are able to obtain a well-paid job in accordance to their specialization upon graduation. Hence, it is important for private HEIs to develop and maintain a distinct and unique image in order to maintain their competitive edge.

The geographical location of the private institution within the country or its proximity to home and environment of the host country has been found to be an influential factor among final year high school students (Joseph \& Joseph, 1998), undergraduates (Beneke \& Human, 2010) and among postgraduates (Poock \& Love, 2001) and local and foreign students in Australia (Mazzarol \& Soutar, 2002).

Many students seriously consider colleges/universities that are relatively close to their homes (Jackson, 1982). Poock and Love (2001) studied on doctoral students identified location as most important factor and Beneke and Human (2010) has classified location as second most important factor for students in deciding the university they want to continue their studies.

Another critical factor is the academic programme. Students evaluate programmes on the following criteria: programme offerings (Nagaraj et al., 2008), quality (Hassan \& Sheriff, 2006), content and structure (Wagner \& Fard, 2009; Joseph \& Joseph, 2000) and international recognition (Maringe \& Carter, 2007). Besides that, the programme's degree conferred by Malaysia's private HEI is likely to be recognized in the respective foreign students' country when it is accreditated by the Malaysian Qualification Agency (MQA).

The last crucial factor is the facilities provided by the institution. It is found that high-standard facilities, such as availability of library facilities, computers, study areas (Price, Matzdorf, \& Agahi, 2003), recreational facilities (Joseph \& Joseph, 2000; Joseph \& Joseph, 1998), laboratory and accommodation (Padlee et al., 2010) does influence a foreign student's choice in choosing private higher education institutions. Well-equipped libraries for research, labs and state of the art lecture halls are all important for providing an environment in which students can learn both successfully and comfortably. Non-academic amenities in sporting, social and health are also important in ensuring that students have a full rounded learning experience. Having a place to stay is of paramount importance, for the comfort and ease of mind of the new student as well as their families, knowing that accommodation is ready and waiting for immediate occupation on arrival. Based on the above arguments, the following hypotheses are proposed:

$\mathrm{H}_{1}$ There is a relationship between cost of education and foreign students' choice of Malaysian private HEI.

$\mathrm{H}_{2}$ There is a relationship between academic reputation and foreign students' choice of Malaysian private HEI. 
$\mathrm{H}_{3}$ There is a relationship between location and foreign students' choice of Malaysian private HEI.

$\mathrm{H}_{4}$ There is a relationship between programme and foreign students' choice of Malaysian private HEI.

$\mathrm{H}_{5}$ There is a relationship between facilities and foreign students' choice of Malaysian private HEI.

\section{Research Methodology}

A survey method using structured questionnaire is used to collect the data. Non-probability sampling technique was chosen for this study in which the sample was selected from the population in some non-random manner. Samples are drawn from 265 respondents using intercept study scientific procedures within five private HEI, and the Structural Equation Model (SEM) is utilized in testing five proposed hypotheses. As Rucks (n.d.), it is common in the intercept study to use several locations in order to increase the quality of the sample. The HEIs are chosen based on, (i) it is a private HEI located in Malaysia, (ii) it is awarded private university status and (iii) has foreign student population in their university. Therefore, five private HEIs are selected within Klang Valley. These five private HEIs were specifically selected is because they do not only fulfill the first two criteria stated above, it is also based on the significant number foreign students studying in their respective campuses.

This study targeted foreign students that are currently studying and living in Malaysia. They are currently pursuing their first year degree. Choosing university students are justified due to two main reasons: (i) both undergraduate and postgraduate student respondents are "real life consumers" (Mattila, 2001) and are the direct consumers of the higher education at Malaysian private HEI; (ii) first year students irrespective of academic level are the best respondents in determining the influential factors of them choosing their respective university. These respondents were selected because they were in a better position to recall what influenced their need recognition to study at their chosen private HEI. Hence, choosing these groups of respondents seemed appropriate to fulfil the research objective for the present study.

The private HEIs have been chosen as the context of this study rather than the public HEIs. As private HEIs may provide similar service (university learning), prospective foreign students normally depend very much on the institutional characteristics, significant others and marketing communication that is available to them. Therefore, these factors seem to be important to the private HEI due to the challenges to differentiate their institution from the other. The scales used in this study have been developed from a review of the relevant literature. In sum, a total of 27 scale items were used to measure the four constructs in the model. Table 3 shows a summary of the number and source of the items used to test each construct.

Table 3. Total of scale items for constructs

\begin{tabular}{lll}
\hline Construct & No. of Items & Sources \\
\hline Cost of education & 4 items & Bonnema and Van de Waldt (2008), Veloutsou et \\
Academic reputation & 5 items & $\begin{array}{l}\text { al. (2004), Gray, Fam and Lalnes (2003), Maringe } \\
\text { and Carter (2007), Cubillo, Cerviño and Sánchez }\end{array}$ \\
Location & 4 items & $(2006)$, Wilkins, Balakrishnan and Huisman \\
Programme & 5 items & $(2013)$ \\
Facilities & 5 items & \\
Decision & 4 items & Al-Fattal (2010) \\
\hline
\end{tabular}

Source: Prepared by author

\section{Data Analysis}

PLS was used for analysis of data as it makes minimal demands in terms of sample size to validate a model compared to alternative structural equation modeling techniques (Urbach \& Ahleman, 2010). Following the recommendation of Hair, Black, Babin and Anderson (2010) a two stage analytical procedures conducted. Firstly conduct a confirmatory factor analysis to assess the measurement model and followed by examining the structural model for hypothesis testing.

\subsection{Measurement Model}

The measurement model is tested by assessing the reliability and validity of the items and constructs in the model. Examining the measurement model is necessary in order to ensure the reliability and validity of the survey instrument. 


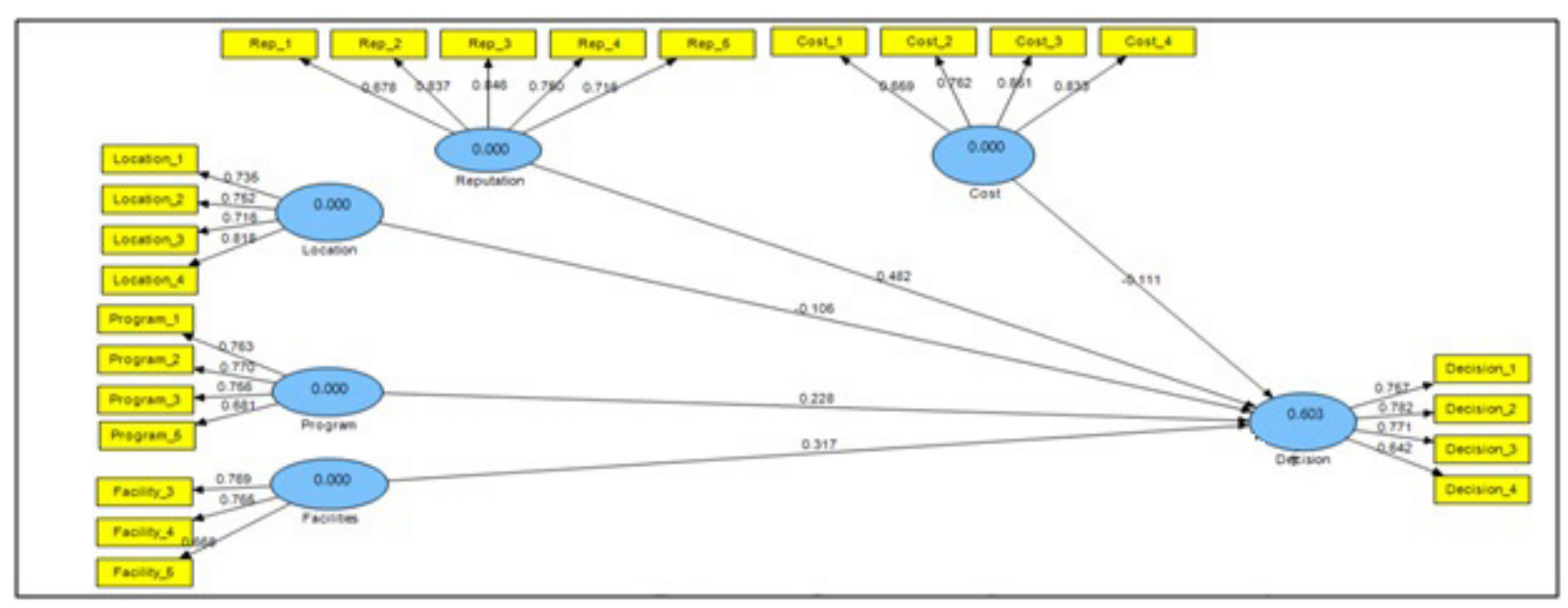

Figure 1. Measurement model

\subsection{Data Reliability}

First, to assess data reliability we examined indicator reliability via squared standardized outer loadings and internal consistency via composite reliability. As shown in table 4 and 5, in each case, all the estimates well exceeded the 0.5 and 0.7 cutoff value respectively that Hair et al. (2010) recommended.

Table 4. Loadings for each variable

\begin{tabular}{llll}
\hline Constructs & Items & Description & Loadings \\
\hline Cost & Cost_1 & The cost of programme fees in the university. & 0.659 \\
& Cost_2 & The cost of accommodation. & 0.762 \\
Decision & Cost_3 & The form of payment was convenient. & 0.851 \\
& Cost_4 & Cost of living. & 0.833 \\
& Decision_1 & My decision was certain. & 0.757 \\
& Decision_2 & It was my own decision, not my parents'. & 0.782 \\
Facility & Decision_3 & My parents and I chose the same university. & 0.771 \\
& Decision_4 & The enrolment day was straightforward. & 0.642 \\
& Facility_1 & Social life in the university. & Removed \\
& Facility_2 & Library facilities in the university. & Removed \\
& Facility_3 & Clubs and societies for students. & 0.769 \\
& Facility_4 & Career advice and internships services. & 0.765 \\
Focation & Facility_5 & Availability of accommodation in the university. & 0.668 \\
& Location_1 & The distance of university from home. & 0.735 \\
& & The existence of private accommodation nearby the & \\
& Location_2 & university. & 0.752 \\
& Location_3 & Safety in the university. & 0.716 \\
& Location_4 & Safety in the area where I live. & 0.818 \\
& Program_1 & The programme is internationally recognised. & 0.763 \\
& Program_2 & Interest in the programme offered. & 0.770 \\
& Program_3 & The programme has recognition by future & \\
& Program_4 & The programme provides career opportunity after & \\
& & graduation. & Removed \\
\hline
\end{tabular}




\begin{tabular}{llll}
\hline \multirow{3}{*}{ Reputation } & Program_5 & Opportunities to continue postgraduate programme. & 0.681 \\
& Rep_1 & The university's high quality courses. & 0.678 \\
& Rep_2 & The university's achievement. & 0.837 \\
& Rep_3 & The university's well-known brand name. & 0.846 \\
& Rep_4 & The university's high standards of education. & 0.750 \\
& Rep_5 & The university's years of academic experience. & 0.716 \\
\hline
\end{tabular}

\subsection{Internal Consistency Reliability}

To assess the internal consistency reliability, both Cronbach alpha and composite reliability were assessed. The acceptable value for both Cronbach alpha and composite reliability according to Hair et al. (2010) must be 0.7 and above as shown in Table 5.

Table 5. Result of Cronbach Alpha and CR for reliability test

\begin{tabular}{lll}
\hline Construct & Cron_Alpha & CR \\
\hline Cost & 0.782 & 0.860 \\
Decision & 0.723 & 0.828 \\
Facility & 0.574 & 0.779 \\
Location & 0.753 & 0.842 \\
Program & 0.730 & 0.831 \\
Reputation & 0.825 & 0.877 \\
\hline
\end{tabular}

\subsection{Convergent Validity}

As shown in Table 6, the AVE for each construct exceeded 0.5. According to Hair, Ringle and Sarstedt (2011) the value of 0.5 and higher for AVE indicates a sufficient degree of convergent validity, meaning that the latent variable explains more than half of its indicators' variance.

Table 6. Result of Average Variance Extracted (AVE)

\begin{tabular}{ll}
\hline Construct & AVE \\
\hline Cost & 0.608 \\
Decision & 0.548 \\
Facility & 0.542 \\
Location & 0.572 \\
Program & 0.552 \\
Reputation & 0.590 \\
\hline
\end{tabular}

\subsection{Discriminant Validity}

To assess the discriminant validity, this study follows that the two measures which was put forward by Hair et al (2011) namely the Fornell and Larcker (1981) criterion and cross loadings. In Table 7, it shows that the Fornell and Larcker (1981) criterion's AVE of each latent variable are greater than the squared correlations between the latent variable and all other variables. 
Table 7. Fornell and Larcker (1981) criterion for discriminant validity of constructs

\begin{tabular}{lllllll}
\hline Construct & Cost & Decision & Facilities & Location & Program & Reputation \\
\hline Cost & $\mathbf{0 . 7 8 0}$ & & & & & \\
Decision & 0.419 & $\mathbf{0 . 7 4 0}$ & & & & \\
Facilities & 0.537 & 0.648 & $\mathbf{0 . 7 3 6}$ & & & \\
Location & 0.585 & 0.450 & 0.540 & $\mathbf{0 . 7 5 6}$ & & \\
Program & 0.562 & 0.528 & 0.480 & 0.520 & $\mathbf{0 . 7 4 3}$ & \\
Reputation & 0.668 & 0.617 & 0.680 & 0.738 & 0.528 & $\mathbf{0 . 7 6 8}$ \\
\hline
\end{tabular}

The second criterion of discriminant validity according to Hair et al. (2011) is that the loadings of an indicator on its assigned latent variable should be higher than its loadings on all other latent variables. As presented in Table 8 , the loadings for each item is in their respective constructs and it is lower on other constructs.

Table 8. Loadings and cross loadings

\begin{tabular}{|c|c|c|c|c|c|c|}
\hline & Cost & Decision & Facilities & Location & Program & Reputation \\
\hline Cost_1 & 0.659285 & 0.289774 & 0.332288 & 0.271995 & 0.387325 & 0.403043 \\
\hline Cost_2 & 0.761668 & 0.278905 & 0.430420 & 0.512465 & 0.452385 & 0.571579 \\
\hline Cost_3 & 0.850894 & 0.369651 & 0.479765 & 0.597115 & 0.461574 & 0.619205 \\
\hline Cost_4 & 0.833186 & 0.355115 & 0.423515 & 0.422894 & 0.452031 & 0.484816 \\
\hline Decision_1 & 0.250129 & 0.757447 & 0.513749 & 0.321872 & 0.358523 & 0.428307 \\
\hline Decision_2 & 0.351169 & 0.781951 & 0.527620 & 0.292628 & 0.399585 & 0.471224 \\
\hline Decision_3 & 0.358250 & 0.770875 & 0.527139 & 0.357798 & 0.393485 & 0.464209 \\
\hline Decision_4 & 0.277883 & 0.641889 & 0.330402 & 0.377294 & 0.420580 & 0.472225 \\
\hline Facility_3 & 0.365756 & 0.517311 & 0.769420 & 0.392360 & 0.312042 & 0.478206 \\
\hline Facility_4 & 0.446371 & 0.449756 & 0.765485 & 0.427190 & 0.407893 & 0.564382 \\
\hline Facility_5 & 0.376882 & 0.458323 & 0.668269 & 0.372765 & 0.345297 & 0.462273 \\
\hline Location_1 & 0.437987 & 0.356881 & 0.374393 & 0.735273 & 0.488199 & 0.491782 \\
\hline Location_2 & 0.466992 & 0.278199 & 0.421797 & 0.751508 & 0.406991 & 0.571792 \\
\hline Location_3 & 0.398298 & 0.266629 & 0.317094 & 0.716232 & 0.270061 & 0.514101 \\
\hline Location_4 & 0.465612 & 0.421394 & 0.493614 & 0.817699 & 0.388728 & 0.644006 \\
\hline Program_1 & 0.423298 & 0.372535 & 0.394186 & 0.374623 & 0.762688 & 0.394488 \\
\hline Program_2 & 0.382238 & 0.432550 & 0.376897 & 0.374597 & 0.770203 & 0.353508 \\
\hline Program_3 & 0.398068 & 0.413371 & 0.333333 & 0.336964 & 0.755739 & 0.359486 \\
\hline Program_5 & 0.484194 & 0.340615 & 0.321963 & 0.477618 & 0.680740 & 0.485598 \\
\hline Rep_1 & 0.423023 & 0.472667 & 0.580628 & 0.473136 & 0.310799 & 0.678268 \\
\hline Rep_2 & 0.564891 & 0.569430 & 0.614743 & 0.576249 & 0.440196 & 0.837164 \\
\hline Rep_3 & 0.561581 & 0.483951 & 0.535318 & 0.652762 & 0.452966 & 0.845736 \\
\hline Rep_4 & 0.538052 & 0.426463 & 0.383092 & 0.563537 & 0.397064 & 0.750346 \\
\hline Rep_5 & 0.470337 & 0.386661 & 0.464267 & 0.576013 & 0.431974 & 0.716150 \\
\hline
\end{tabular}


The measures for reliability and validity showed that the model presented in this study has a sufficient level of reliability and validity.

\subsection{Structural Model}

With the adequate measurement model and the acceptable level of reliability and validity the structural path modeling were assessed to test the proposed hypotheses. To assess the study hypotheses, we estimated a structural model using Smart Pls. The path coefficients were produced using a bootstrapping procedure with 5000 bootstrap samples (Hair et al., 2011). Critical $t$-values for a two-tailed test are 1.65 (significance level $=10$ percent), 1.96 (significance level $=5$ percent), and 2.58 (significance level $=1$ percent). For this study 10 percent significant level (t-Value: 1.65) was used as a statistical decision criterion. The result of each hypothesis will be discussed in the following sections. Results of hypotheses tests on the model's direct relationships are presented in Table 9.

Table 9. Hypotheses on the direct relationships

\begin{tabular}{|c|c|c|c|c|c|c|}
\hline Hypothesis & Description & Beta & $\mathrm{R}^{2}$ & Std Error & T-Value & Decision \\
\hline $\mathrm{H}_{1}$ & $\begin{array}{l}\text { Relationship of Cost of Education and } \\
\text { Foreign Students' Choice }\end{array}$ & -0.111 & 0.180 & 0.061 & $1.827^{*}$ & Supported \\
\hline $\mathrm{H}_{2}$ & $\begin{array}{l}\text { Relationship of Academic Reputation } \\
\text { and Foreign Students' Choice }\end{array}$ & 0.482 & 0.386 & 0.101 & $4.798 * * *$ & Supported \\
\hline $\mathrm{H}_{3}$ & $\begin{array}{l}\text { Relationship of Location and Foreign } \\
\text { Students' Choice }\end{array}$ & -0.106 & 0.212 & 0.077 & 1.375 & $\begin{array}{l}\text { Not } \\
\text { Supported }\end{array}$ \\
\hline $\mathrm{H}_{4}$ & $\begin{array}{l}\text { Relationship of Programme and } \\
\text { Foreign Students' Choice }\end{array}$ & 0.228 & 0.285 & 0.063 & $3.618^{* * *}$ & Supported \\
\hline $\mathrm{H}_{5}$ & $\begin{array}{l}\text { Relationship of Facilities and Foreign } \\
\text { Students' Choice }\end{array}$ & 0.317 & 0.427 & 0.070 & $4.555 * * *$ & Supported \\
\hline
\end{tabular}

Note. $*$ Sig at $0.10, * *$ Sig at $0.05, * * *$ Sig at 0.01

\section{Discussion and Conclusion}

\subsection{Relationship between Cost of Education and Foreign Students' Choice of Malaysian Private HEI}

The findings show that cost of education has a significant influence on students' choice of Malaysian private HEI however this relationship is negative. Cost of education touches on mode of payment, cost of programme and cost of living. Easy mode of payment is important to pay the university's tuition fees. This is to reduce the occurrence of families not being able to pay on time which leads to foreign students to be barred from attending classes and to sit for final exams as well as being unable to view their academic results. As for the cost of programme fees in private higher education institutions, it is far more expensive than public universities. Jackson's (1986) and Allen and Shen (1999) findings have also revealed that cost is significantly negatively related to college choice. There is an empirically significant enrolment response to the opportunity cost of enrolment (Allen \& Shen, 1999). Besides that, the cost of living influences foreign students' in choosing their universities overseas. However the overall cost of education and living costs in Malaysia is still the lowest in comparison with countries that offer programmes using English medium as shown in Table 10. 
Table 10. Cross-country comparison of cost of education for a bachelor's degree in arts or business programmes for foreign students

\begin{tabular}{llll}
\hline $\begin{array}{l}\text { Country } \\
\text { (public/private institutions) }\end{array}$ & $\begin{array}{l}\text { Tuition Fees } \\
\text { (per academic year) }\end{array}$ & $\begin{array}{l}\text { Living Costs } \\
\text { (per year) }\end{array}$ & $\begin{array}{l}\text { Total Education Cost } \\
\text { (per annum) }\end{array}$ \\
\hline Australia (public) & USD8,500 & USD8,500 & USD17,000 \\
Canada (public) & USD7,500 & USD9,000 & USD16,500 \\
France (public) & Minimal & USD13,000 & USD13,000 \\
Malaysia (private) & USD4,600 & USD4,000 & USD9,000 \\
New Zealand (public) & USD10,000 & USD11,500 & USD21,5000 \\
Singapore (private) & USD6,500 & USD10,000 & USD16,500 \\
United Kingdom (public) & USD14,000 & USD12,500 & USD26,500 \\
USA (public) & USD13,000 & USD12,000 & USD25,000 \\
USA (private) & USD22,000 & USD13,000 & USD35,000
\end{tabular}

Source: Study in Malaysia Handbook (International Edition)

\subsection{Relationship between Academic Reputation and Foreign Students' Choice of Malaysian Private HEI}

The findings show that academic reputation has a positive significant influence on foreign students' choice of Malaysian private HEI. This is in line with the findings of Beneke and Human (2010), Nagaraj et al. (2008) and LeBlanc and Nguyen (1997). Reputation in terms of a well-known brand name of the institution highly influences foreign students' choice of Malaysian private HEI. Recognition of the university's brand name is one of the key components to create awareness of the university and the programmes being offered. The university's high standard of education is crucial as well. The standard can be in terms of the language medium used in teaching (i.e. English language) which differs from their home country's medium of instruction. The institution's years of academic experience are also an important component for foreign students. It is perceived that the longer the university has been established, the more reputable the university is.

\subsection{Relationship between Location and Foreign Students' Choice of Malaysian Private HEI}

It is found that location of the private HEI does not significant influence on foreign students' choice of Malaysian private higher education institutions. Foreign students are not very particular about the distance of the institution from their accommodation or the availability of private accommodation nearby the institution. It seems that foreign students place a priority on the programmes rather than the physical location of the institution.

\subsection{Relationship between Programme and Foreign Students' Choice of Malaysian Private HEI}

The findings show that programme has a positive significant influence on foreign students' choice of Malaysian private HEI. Firstly, foreign students' place high interest in the programmes offered. There may be cases where the institutions in their respective home country do not offer the programme that they are interested in. They are willing to venture abroad for an internationally recognized programme especially when it is recognized in their home country. The third consideration of importance is that the programme is recognized by future employers.

Getting an overseas education puts a student in a prestigious position since the student would be considered to have received a more rounded education through exposure to a different culture, language and environment, outside of his own country. A foreign degree sets these students apart from other students that have studied locally. A majority of the multinational companies place priorities for job candidates with foreign degrees and this creates a competitive advantage for foreign students' if/when they return to their home country.

\subsection{Relationship between Facilities and Foreign Students' Choice of Malaysian Private HEI}

The findings show that facilities have a positive significant influence on foreign students' choice of Malaysian private HEI. The first aspect that is clubs and societies is important for foreign students because it is an avenue for development of leadership and character, leisure or entertainment. Being a student in a foreign country without the family can be emotionally taxing for an individual who is far away from home. A different culture, food and place may make it difficult to cope in the first few months and loneliness will set in. Enrolling in different clubs and actively participating in different activities will push new students to interact with other students of different nationalities, beliefs and attitudes. Students will also be slowly exposed to the wonders of 
Malaysia with all its cultural diversity, varied culinary delights and scenic treasures.

Whilst participation in student clubs and societies will help foreign students to interact and assimilate themselves within the community, topmost in their agenda are still their future career prospects. Therefore the availability of career advice and internship services in the private higher education institutions cater to that need. Career advice is normally sought nearing the end of the student's academic year and especially during the last semester. Counsellors are able to give advice on careers that best fit the students' qualifications. Students have the choice whether to return back to their home country to start their working life or to continue their tertiary studies. As for internships, the timing and duration will vary from one private higher education institution to the other. The internship can be completed in one stretch within a year or at the end of the student's academic studies and the duration can be a minimum of between 2 months to 6 months.

\section{Conclusion}

In conclusion, this study has demonstrated that institutional characteristics namely cost of education, academic reputation, programme and facilities are significantly important in measuring foreign students' choice of Malaysian private HEI. Researchers and strategists who aim to nurture these decision choices should pay close attention to these crucial factors. These factors may further help Malaysian private HEIs to effectively utilize their resources and ultimately helps to achieve Malaysia's aspiration to achieve 200,000 foreign students by year 2020. According to the findings, it advised that, the strategists develop a more tailored programmes based on the unique requirements of private HEIs. This is crucial since the findings reveal that the academic reputation of the institution is the most influential factor for foreign students in choosing their universities. The reputation should focus more on building the Malaysian's higher education as a national brand. The current Malaysian strategies on internationalization of higher education tend to build the national prestige of Malaysian higher education on existing national accomplishments. Malaysia should also highlight its competitive advantages through matters such as one of the fastest developing country within South East Asia and all programmes taught in private HEIs are conducted in English. Besides that, it is a melting pot of cultures that can be an attraction by itself.

\section{References}

AL-Fattal, A. (2010). Understanding Students' Choice of University and Marketing Strategies in Syrian Private Higher Education (Unpublished $\mathrm{PhD}$ Thesis, University of Leeds, UK).

Banks, M., Olsen A., \& Pearce, D. (2007). Global Student Mobility: An Australian perspective five years on. IDP Education Pty Ltd.

Beneke, J., \& Human, G. (2010). Student recruitment marketing in South Africa-An exploratory study into the adoption of a relationship orientation. African Journal of Business Management, 4(4), 435-447.

Bonnema, J., \& Vander-Waldt, D. (2008). Information and source preferences of a student market in higher education. The International Journal of Educational Management, 22(4), 314-327. http://dx.doi.org/10.1108/09513540810875653

Cubillo, J. M., Cerviño, J., \& Sánchez, J. (2006). International Students' Decision-Making Process. The International Journal of Educational Management, 20(2), 101-115. http://dx.doi.org/10.1108/09513540610646091

Dora, M. T. H., Ibrahim, N. R. D. W., Ramachandran, S. D., Kasim, A., \& Saad, M. S. M. (2009). A study on factors that influence choice of Malaysian institution of higher learning for international graduate students. Journal of Human Capital Development, 2(1), 105-113.

Economic Transformation Programme. (2010). Chapter 14: Transforming Education as an Engine of Growth. $A$ road map for Malaysia, 475-509.

Fornell, C., \& Larcker, D. F. (1981). Evaluating structural equation models with unobserved variables and measurement error. Journal of Marketing Research, 18, 39-50. http://dx.doi.org/10.2307/3151312

Ghazali, M. H. M. Z., \& Kassim, M. S. (2003). The development of global education in Malaysia: Strategies for Internationalization. Malaysian Management Review, 38(3), 75-85.

Gray, B. J., Fam, K. S., \& Lalnes, V. A. (2003). Branding universities in Asian markets. Journal of Product \& Brand Management, 12(2), 108-120. http://dx.doi.org/10.1108/10610420310469797

Hair, J. F., Black, W. C., Babin, B. J., \& Anderson, R. E. (2010). Multivariate Data Analysis (7th ed.). Upper Saddle River, NJ: Prentice Hall.

Hair, J. F., Ringle, C. M., \& Sarstedt, M. (2011). PLS-SEM: Indeed a silver bullet. Journal of Marketing Theory 
and Practice, 19(2), 139-151. http://dx.doi.org/10.2753/MTP1069-6679190202

Hassan, F. H., \& Sheriff, N. M. (2006). Students' need recognition for higher education at private colleges in Malaysia: An exploratory perspective. Sunway Academic Journal, 3, 61-71.

Jackson, G. A. (1982). Public efficiency and private choice in higher education. Educational Evaluation and Policy Analysis, 4(2), 237-247. http://dx.doi.org/10.3102/01623737004002237

Joseph, M., \& Joseph, B. (2000). Indonesian students' perceptions of choice criteria in the selection of a tertiary institution: Strategic implications. International Journal of Educational Management, 14(1), 40-44. http://dx.doi.org/10.1108/09513540010310396

Joseph, M., \& Joseph, B. (1998). Identifying need of potential students in tertiary education for strategy development. Quality Assurance in Education, 6(2), 90-96. http://dx.doi.org/10.1108/09684889810205741

LeBlanc, G., \& Nguyen, N. (1997). Searching for excellence in business education: An exploratory study of customer impressions of service quality. International Journal of Educational Management, 11(2), 72-79. http://dx.doi.org/10.1108/09513549710163961

Maringe, F., \& Carter, S. (2007). International students' motivations for studying in UK HE: Insights into the choice and decision making of African students. International Journal of Education Management, 21(6), 459-475. http://dx.doi.org/10.1108/09513540710780000

Mattila, A. S. (2001). The effectiveness of service recovery in a multi-industry setting. Journal of Services Marketing, 15(7), 583-596. http://dx.doi.org/10.1108/08876040110407509

Mazzarol, T., \& Soutar, G. N. (2002), Push-pull factors influencing international student destination choice. $\begin{array}{llll}\text { International Journal of Educational } & \text { Management, } & 16(2), & \text { 82-90. }\end{array}$ http://dx.doi.org/10.1108/09513540210418403

Migin, M. W., Yajid, M. S., Khatibi, A., \& Falahat, M. (2014). Influential drivers for postgraduate students inMalaysia's Higher Education. Aust. J. Basic \& Appl. Sci., 8(17), 617-621.

Ministry of Higher Education (MOHE). (2012). Statistics of higher education of Malaysia.

Ministry of Higher Education (MOHE). (2010). Statistics of higher education of Malaysia.

Nagaraj, S., Munisamy, S., Jaafar, N. I. M., Wahab, D. A., \& Mirzaei, T. (2008). How do undergraduates choose their university? A study of first year University of Malaya students (FEA Working Paper, No. 2008-8, University of Malaya, Malaysia).

Padlee, S. F., Kamaruddin, A. R., \& Baharun, R. (2010). International Students' Choice Behavior for Higher Education at Malaysian Private Universities. International Journal of Marketing Studies, 2(2), 202-211. http://dx.doi.org/10.5539/ijms.v2n2p202

Poock, M. C., \& Love, P. G. (2001). Factors influencing the program choice of doctoral students in higher education administration. Naspa Journal, 38(2), 203-223.

Price, I., Matzdorf, L., \& Agahi, R. (2003). The impact of facilities on student choice of university. International Journal of Educational Management, 21(10), 212-222.

REHDA Institute. (2010). Economic Transformation Programme. Retrieved from $\mathrm{http}: / /$ www.rehdainstitute.com/index.php?option $=$ com_content\&view=article\&id=75

Sang, S., Lee, J. D., \& Lee, J. (2010). E-government adoption in Cambodia: A partial least squares approach. Transforming Government: People, Process, and Policy, 4(2), 138-157. http://dx.doi.org/10.1108/17506161011047370

Study in Malaysia. (2011). Retrieved from http://www.studymalaysia.com/education/art_msia.php?id=affordable

UNESCO Institute of Statistics. (2008), Global Education Digest 2008. Montreal: UNESCO-Institute of Statistics.

Urbach, N., \& Ahleman, F., (2010). Structural equation modelling in information systems research using partial least squares. Journal of Information Technology Theory and Application, 11(2).

Veloutsou, C., Lewis, J. W., \& Paton, R. A. (2004). University Selection: Information Requirements and Importance. The International Journal of Educational Management, 18(2/3), 160-171. http://dx.doi.org/10.1108/09513540410527158

Wagner, K., \& Fard, P. Y. (2009). Factors influencing Malaysian students' intention to study at a higher 
educational institution. E-Leader Kuala Lumpur, 1-12.

Wilkins, S., Balakrishnan, M. S., \& Huisman, J. (2012). Student choice in higher education: Motivations for choosing to study at an international branch campus. Journal of Studies in International Education, 16(5), 413-433. http://dx.doi.org/10.1177/1028315311429002

\section{Copyrights}

Copyright for this article is retained by the author(s), with first publication rights granted to the journal.

This is an open-access article distributed under the terms and conditions of the Creative Commons Attribution license (http://creativecommons.org/licenses/by/3.0/). 